\title{
Analysis of Key Performance Indicators of Economic Development of Russian Regions
}

\author{
Smirnov V.V.* \\ Chuvash State University \\ Cheboksary, Russia \\ walera712006@mail.ru \\ Kadyshev E.N. \\ Chuvash State University \\ Cheboksary, Russia
}

\author{
Semenov V.L. \\ Chuvash State University \\ Cheboksary, Russia
}

\author{
Zakharova A.N. \\ Chuvash State University \\ Cheboksary, Russia
}

\author{
Chaynikov V.N. \\ Chuvash State University \\ Cheboksary, Russia
}

\begin{abstract}
The subject of study is the economy of the regions of Russia. The topic of the study is the analysis of key performance indicators (KPI) of the development of the economy of the Russian regions. The aim of the work was to determine the KPI of the development of the economy of the regions of Russia, changes and opportunities for their improvement in modern conditions. The study is based on a systematic approach using statistical, comparative and logical methods of analysis. The article substantiates the relevance of the KPI assessment of the development of the economy of the regions of Russia in modern conditions. The KPI analogy is revealed for the personnel of the organization and the economy of the regions of Russia. The KPI analysis methodology is analyzed and the main dependencies and characteristics are identified as part of a unified system of balanced indicators, which establishes causal relationships between the goals of the personnel and the organization, a particular region and Russia as a whole. As a result of assessing the median and variance of the growth rate of KPI values for the development of the regional economy, as well as their standard deviations, three levels with pronounced priorities of the administrative-territorial division are revealed. The results of the study should be applied to state authorities in determining the strategic goals of economic growth and development of Russian regions, as well as in the process of choosing managerial decisions to increase the KPI values of individual regions. In modern conditions, the possibilities for increasing the KPI of the development of the economy of the Russian regions are limited by the raw material profile of the Russian economy. Stably high KPI values are demonstrated by oil and gas regions, which for the most part are regions than republics. The economic development efficiency of subsidized regions is determined by the volume of federal subsidies and subventions. Areas that do not have political independence are becoming a priority form of government and a form of increasing KPI values for the development of the economy of the Russian regions.
\end{abstract}

Keywords - key performance indicators, opportunities, changes, development, strategic goals, growth rates.

\section{INTRODUCTION}

Modern problems of effective organization of the Russian economy are associated with the lack of a clear policy and development strategy for its regions. An essential condition is the displacement of the target vector of the effective organization of the Russian economy from country to region. In this context, Russia is represented as a corporation - a legal entity, pursuing the goal of "making a profit" as its main activity, providing for the participation of regions, which, in turn, have a separate property complex used in the process of reproduction.

There is a legitimate need to assess the role of each region in the reproductive process of the national economy. This will allow hierarchically ranking the regions of Russia by the level of business activity, as well as determine the possibilities of increasing the effectiveness of their activities, focusing on the best practices of active regions.

To assess the business activity of the region, we will use the criteria for assessing the achievement of strategic and tactical economic goals. We select key performance indicators (KPI) as these criteria. KPIs allow orienting the Rossiya corporation towards achieving strategic and tactical goals, and monitoring the business activity of its regions.

Going deeper into the etymology of the word "performance", two principles should be distinguished effectiveness and efficiency [1-3]. According to the ISO 9000:2015 standard, effectiveness is the degree of achievement of planned results, and efficiency is the ratio between achieved results and resources expended [4-6]. Therefore, KPI is considered as a key indicator of the result of activity - the degree of achievement and the cost of obtaining the result.

Most corporate performance management systems originate from models developed by Frederick Taylor over a hundred years ago for discrete production. The evolution of performance management over the past 30 years has led to the development of non-financial motivation tools, as well as to the rise and subsequent popularity of the idea of rigidly ranking the organization's employees depending on the results achieved [7]. 
However, the regions can act as employees as subjects of the Rossiya corporation, thereby simplifying the problem of evaluating the performance of executive authorities in the field. The effectiveness of regional authorities can be assessed bypassing the subjective performance indicators of individual officials, focusing on the KPI of regional economic development.

\section{LITERATURE REVIEW}

The basis of KPI is the "management by goals" method, management activities that foresee the possible results of activities and plan ways to achieve results. The founder of this method and the corresponding system for assessing the achievement of results is Peter Ferdinand Drucker [8, 9].

According to Drucker, managers should avoid "time traps" when they are involved in the process of solving current daily tasks, as this leads to the fact that they begin to forget to perform tasks aimed at achieving results (goals). According to Drucker, only a few areas of management have such a big impact on an organization as a KPI score. For example, $60 \%$ of top managers in the United States are dissatisfied with their KPI rating systems, in Russia they are more than $80 \%$. This discontent is expressed in the absence of a connection between plans, execution and outcome.

KPIs are a part of a balanced scorecard that establishes cause-effect relationships between goals (strategy) and indicators (quality effects, project performance) in order to see patterns and mutual factors of influence in business - the dependence of some business results on others [10,11].

The idea of KPI is to detail the strategic goals of the company to the level of an employee [12]. In evaluation practice, the following KPI dependencies are applied on: result (how many and what result produced); costs (how much resources have been spent); functioning (performance indicators of business processes); productivity (derived indicators characterizing the relationship between the result obtained and the time spent on its achievement). Efficiency is a derivative indicator that characterizes the ratio of the result to the cost of resources $[13,14]$.

Seven characteristics of KPI are distinguished: 1) nonfinancial nature of indicators (their value is not expressed in dollars, euros, yen, pounds, etc.); 2) they are often monitored (for example, on a daily or even hourly basis); 3) require the intervention of the CEOs and top managers; 4) require understanding and adequate corrective actions of all personnel; 5) involve the responsibility of a particular person or team; 6) have a significant impact (for example, affect the most significant critical success factors and more than one component of a balanced scorecard); 7) have a positive impact (for example, positively affect all other indicators of the organization).

The authorities of the regions of Russia, guided by the Federal Law "On Strategic Planning in the Russian Federation" [15], as a rule, use the list of indicators contained in it that are suitable for monitoring regional target programs and do not meet the tasks of developing a unified system for assessing the KPI of regional economic development. The Kremlin has developed a common KPI system for the internal political block of the presidential administration and vice governors for domestic politics. The level of trust in the president and governors will be evaluated. KPI for elections is also introduced. The government will evaluate the effectiveness of regional authorities in accordance with the "List of indicators for assessing the effectiveness of the activities of senior officials (heads of the highest executive bodies of state power) of the constituent entities of the Russian Federation and the activities of executive bodies of the constituent entities of the Russian Federation" [16].

\section{METhODOLOGY}

The relevance of the use of KPI is determined by the Federal Law "On Strategic Planning in the Russian Federation" [15], the Decree of the President of the Russian Federation "On Evaluating the Efficiency of the Activities of Senior Officials (Heads of the Highest Executive Bodies of State Power) of the Subjects of the Russian Federation and the Activities of the Executive Bodies of the Subjects of the Russian Federation") - 'List of indicators"'. The following are highlighted in the list of performance indicators of senior officials: the number of highly productive jobs in the extrabudgetary sector of the economy; level of real average monthly salary; volume of investments in fixed assets, with the exception of investments in infrastructure monopolies (federal projects) and budget allocations from the federal budget; level of poverty; natural population growth [16].

Focusing on the above list, given the standard of data provided by the Federal State Statistics Service of the Russian Federation [17], to assess the KPI of the development of the economy of the regions of Russia, we distinguish the following aggregated indicators: GRP; value of fixed assets; labor force at the age of 15-72 years; investment in fixed assets; labor productivity; real cash incomes of the population and consumer spending on average per capita.

The structure of indicators may vary depending on the introduced legal criteria for assessing the effectiveness of the activities of regional authorities, the availability of statistical data.

To understand the methodology for determining the KPI of the development of the economy of the regions of Russia, we present the reverse sequence of calculation (from the final result to the beginning of the assessment). Firstly, to reduce the error in the KPI calculations, the development of the Russian regions is evaluated according to two interdependent criteria $K P I_{M e}$ and $K P I_{\sigma^{2}}$

$$
K P I_{M e}=\frac{M e_{\Delta G R_{n}}}{\Delta M e_{G R}}
$$

where $M e_{\Delta G R_{n}}$ is the median of the standard deviations of the growth rates of aggregate indicators of the economy of the regions of Russia; $\Delta M e_{G R_{n}}$ is the standard deviation of the median values of the growth rates of the aggregate indicators of a particular region; $G R_{n}$ are growth rates of aggregated indicators: $G R_{1}$ are the growth rates of GRP, \%; $G R_{2}$ are the growth rate of the value of fixed assets, \%;GR 3 is the growth rate of the labor force at the age of $15-72$ years, $\%$; $G R_{4}$ is growth rate of investments in fixed assets, $\% ; G R_{5}$ is the 
growth rate of labor productivity, $\% ; G R_{6}$ is growth rate of real cash income of the population, $\% ; G R_{7}$ is the growth rate of consumer spending on average per capita, $\%$.

Similarly for $K P I_{\sigma^{2}}$,

Secondly:

- the median is determined by the formula

$$
M e=X_{M e}+i_{M e} \cdot \frac{\frac{\sum f}{2}-S_{M e-1}}{f_{M e}}
$$

where $M e$ is the median; $X_{M e}$ is the lower boundary of the median interval (the interval, the accumulated frequency of which exceeds half the sum of all frequencies); $i_{M e}$ is the value of the median interval; $f$ is the frequency (how many times in a row one or another value occurs); $S_{M e-1}$ is the sum of the frequencies of the intervals of the previous medians;

- standard deviation

$$
\sigma=\sqrt{\sigma^{2}}
$$

- variance

$$
\sigma^{2}=\frac{\sum(x-\bar{x})^{2}}{(n-1)}
$$

where $x$ is sample mean; $n$ is sample size.

\section{ANALYSIS}

To analyze the functionality of the regional structure of the modern economy of Russia, we will use the statistical data of the Federal State Statistics Service of the Russian Federation [17].

As a result of estimation of median values (Me) and variance $\left(6^{2}\right)$ of GRP growth rates, cost of fixed assets, labor force at the age of 15-72 years, investments in fixed assets, labor productivity, real incomes of the population, average consumer spending per capita, using the methodology for assessing KPI, identified three levels of regional development: $\mathrm{KPI}_{\mathrm{Me}}>1, \mathrm{KPI}_{\mathrm{Me}}=1, \mathrm{KPI}_{\mathrm{Me}}<1$, and $\mathrm{KPI}_{6}{ }^{2}>1 ; \mathrm{KPI}_{6}{ }^{2}=1$; $\mathrm{KPI}^{2}<1$ (Table 1$)$.

Leaders in $\mathrm{KPI}_{\mathrm{Me}}>1$ : Volgograd, Tyumen (without autonomous regions), Kostroma, Tver, Ulyanovsk regions; Republics - Karachay-Cherkess, Buryatia, Udmurt, KhantyMansi Autonomous Okrug - Ugra; Altai region. Outsiders in $\mathrm{KPI}_{\mathrm{Me}}<1$ : Sevastopol; Republics of Crimea, Tuva and Khakassia; Krasnodar region; Nenets and Chukotka Autonomous Districts; Amur and Jewish Autonomous Region.

As a result of the $\mathrm{KPI}_{6}{ }^{2}$ assessment, three levels of regional development were identified $-\mathrm{KPI}_{6}{ }^{2}>1 ; \mathrm{KPI}_{6}{ }^{2}=1$; $\mathrm{KPI}_{6}{ }^{2}<1$. Leaders in $\mathrm{KPI}_{6}{ }^{2}>1$ : Tula, Smolensk, Kaluga, Tomsk, Omsk, Orenburg and Tyumen regions; Republic of Tatarstan; Krasnoyarsk region; Khanty-Mansiysk Autonomous Okrug - Ugra.

Outsiders in $\mathrm{KPI}_{6}{ }^{2}<1$ : Sevastopol; Republic of Crimea, Kalmykia and Mari El; Chukotka Autonomous Region; Arkhangelsk (without autonomous region); Vologda, Leningrad and Magadan regions; Kamchatka Krai.
TABLE I. THE GROWTH RATE OF KPI VALUES, THEIR MEDIAN,

\begin{tabular}{|c|c|c|}
\hline Region & KPI Me & KPI ${ }_{6}^{2}$ \\
\hline Russian Federation & 1.1 & 12.8 \\
\hline Central Federal District & 1.0 & 6.8 \\
\hline Belgorod region & 1.0 & 1.3 \\
\hline Bryansk region & 1.0 & 0.5 \\
\hline Vladimir region & 1.2 & 3.3 \\
\hline Voronezh region & 1.1 & 4.3 \\
\hline Ivanovo region & 1.2 & 0.6 \\
\hline Kaluga region & 1.0 & 8.6 \\
\hline Kostroma region & 1.3 & 0.7 \\
\hline Kursk region & 1.1 & 1.8 \\
\hline Lipetsk region & 1.0 & 2.2 \\
\hline Moscow region & 1.1 & 3.8 \\
\hline Oryol Region & 1.0 & 3.6 \\
\hline Ryazan Oblast & 0.8 & 0.6 \\
\hline Smolensk region & 1.2 & 8.9 \\
\hline Tambov Region & 0.9 & 1.5 \\
\hline Tver region & 1.3 & 0.9 \\
\hline Tula region & 0.9 & 10.2 \\
\hline Yaroslavskaya oblast & 1.1 & 1.2 \\
\hline Moscow & 0.9 & 3.0 \\
\hline Northwestern Federal District & 1.0 & 1.8 \\
\hline Republic of Karelia & 1.1 & 2.0 \\
\hline Komi Republic & 0.6 & 0.5 \\
\hline Arhangelsk region & 0.9 & 0.5 \\
\hline \multicolumn{3}{|l|}{ including: } \\
\hline Nenets Autonomous Okrug & 0.5 & 0.2 \\
\hline Arkhangelsk region without an autonomous region & 1.2 & 0.2 \\
\hline Vologda Region & 1.1 & 0.2 \\
\hline Kaliningrad region & 1.0 & 0.5 \\
\hline Leningrad region & 0.9 & 0.2 \\
\hline Murmansk region & 0.7 & 0.6 \\
\hline Novgorod region & 0.8 & 1.3 \\
\hline Pskov region & 1.2 & 2.9 \\
\hline St. Petersburg & 1.0 & 0.4 \\
\hline Southern Federal District & 0.6 & 0.8 \\
\hline Republic of Adygea & 1.2 & 1.0 \\
\hline Republic of Kalmykia & 0.9 & 0.1 \\
\hline Republic of Crimea & 0.2 & 0.0 \\
\hline Krasnodar region & 0.4 & 0.4 \\
\hline Astrakhan region & 1.0 & 0.4 \\
\hline Volgograd region & 1.4 & 1.0 \\
\hline Rostov region & 1.1 & 1.8 \\
\hline Sevastopol & 0.0 & 0.0 \\
\hline North Caucasus Federal District & 0.9 & 5.3 \\
\hline The Republic of Dagestan & 0.9 & 2.3 \\
\hline The Republic of Ingushetia & 0.8 & 0.3 \\
\hline Kabardino-Balkarian Republic & 1.0 & 0.6 \\
\hline Karachay-Cherkess Republic & 1.4 & 1.1 \\
\hline Republic of North Ossetia - Alania & 1.2 & 0.6 \\
\hline Chechen Republic & 0.7 & 0.8 \\
\hline Stavropol region & 1.0 & 1.6 \\
\hline Volga Federal District & 1.0 & 4.7 \\
\hline Republic of Bashkortostan & 1.0 & 0.7 \\
\hline Mari El Republic & 0.7 & 0.2 \\
\hline The Republic of Mordovia & 1.1 & 1.9 \\
\hline Republic of Tatarstan & 1.2 & 5.6 \\
\hline Udmurtia & 1.3 & 0.8 \\
\hline Chuvash Republic & 1.0 & 3.9 \\
\hline Perm region & 1.2 & 0.9 \\
\hline Kirov region & 1.2 & 2.5 \\
\hline Nizhny Novgorod Region & 1.0 & 2.3 \\
\hline Orenburg region & 1.2 & 4.8 \\
\hline Penza region & 1.2 & 0.7 \\
\hline Samara Region & 0.8 & 0.6 \\
\hline
\end{tabular}
VARIANCE, STANDARD DEVIATION OF THE MEDIAN AND VARIANCE, KPI, 2012-2017 


\begin{tabular}{|l|l|l|}
\hline Saratov region & 1.1 & 4.0 \\
\hline Ulyanovsk region & 1.3 & 0.9 \\
\hline Ural federal district & 1.2 & 7.5 \\
\hline Kurgan region & 0.9 & 1.6 \\
\hline Sverdlovsk region & 1.1 & 3.7 \\
\hline Tyumen region & 1.2 & 4.3 \\
\hline including: & & \\
\hline Khanty-Mansiysk Autonomous Okrug - Ugra & 1.3 & 4.5 \\
\hline Yamal-Nenets Autonomous Okrug & 0.9 & 0.6 \\
\hline Tyumen region without autonomous districts & 1.4 & 0.9 \\
\hline Chelyabinsk region & 1.1 & 2.5 \\
\hline Siberian Federal District & 1.1 & 0.8 \\
\hline Altai Republic & 0.9 & 1.7 \\
\hline The Republic of Buryatia & 1.4 & 1.0 \\
\hline Tyva Republic & 0.6 & 0.3 \\
\hline The Republic of Khakassia & 0.6 & 0.5 \\
\hline Altai region & 1.3 & 1.0 \\
\hline Zabaykalsky Krai & 1.0 & 1.1 \\
\hline Krasnoyarsk region & 0.9 & 5.3 \\
\hline Irkutsk region & 1.1 & 2.1 \\
\hline Kemerovo region & 1.1 & 0.5 \\
\hline Novosibirsk region & 1.0 & 1.7 \\
\hline Omsk region & 1.3 & 4.8 \\
\hline Tomsk region & 1.2 & 5.6 \\
\hline Far Eastern Federal District & 0.9 & 1.0 \\
\hline The Republic of Sakha (Yakutia) & 0.8 & 0.4 \\
\hline Kamchatka Krai & 0.7 & 0.2 \\
\hline Primorsky Krai & 1.0 & 0.5 \\
\hline Khabarovsk region & 0.7 & 2.5 \\
\hline Amur region & 0.5 & 0.2 \\
\hline Magadan Region & 0.9 & 0.2 \\
\hline Sakhalin Oblast & 0.7 & 0.4 \\
\hline Jewish Autonomous Region & 0.5 & 0.3 \\
\hline Chukotka Autonomous Okrug & 0.5 & 0.1 \\
\hline & & \\
\hline
\end{tabular}

a. Source: calculated and compiled according to the Federal State Statistics Service of the Russian Federation. "Regions of Russia. Socio-economic indicators - 2018" Bank of ready-mad documents. http://www.gks.ru/bgd/regl/b18_14p/Main.htm. Accessed on 09/18/2019.

In terms of combined KPIMe and $\mathrm{KPI}_{6}{ }^{2}$, the clear leader is the Khanty-Mansi Autonomous Okrug - Ugra which is a part of the Tyumen region and is located in the Urals Federal District. The region is a leader in a number of key economic indicators: oil production; electricity production; in terms of industrial production; gas production; tax revenues to the budget system; volume of investments in fixed assets.

We can distinguish a number of regions with a sufficiently high KPI level for the raw material profile of the Russian economy: Vladimir, Volgograd, Voronezh, Irkutsk, Kirov, Kursk, Moscow, Omsk, Pskov, Rostov, Saratov, Sverdlovsk, Smolensk, Tomsk, Chelyabinsk and Yaroslavl regions; Republics - Tatarstan, Karachay-Cherkess, Karelia and Mordovia.

Based on the foregoing, it can be argued that high KPIs are inherent in regions than republics. And this is natural for a Russian economy with a commodity profile, when the region does not have any political independence, is not a subject of international law, and the head of the region is a government official appointed and dismissed by the head of state from the post and bearing civil and criminal liability for violations the law.

Among the federal districts, the leader is the Ural and Central Federal Districts, in which there are no republics.
The KPI differentiation of the development of the economies of the Russian regions shows significant differences between $\mathrm{KPI}_{\mathrm{Me}}$ and $\mathrm{KPI}_{6}{ }^{2}$ (Figure 1).

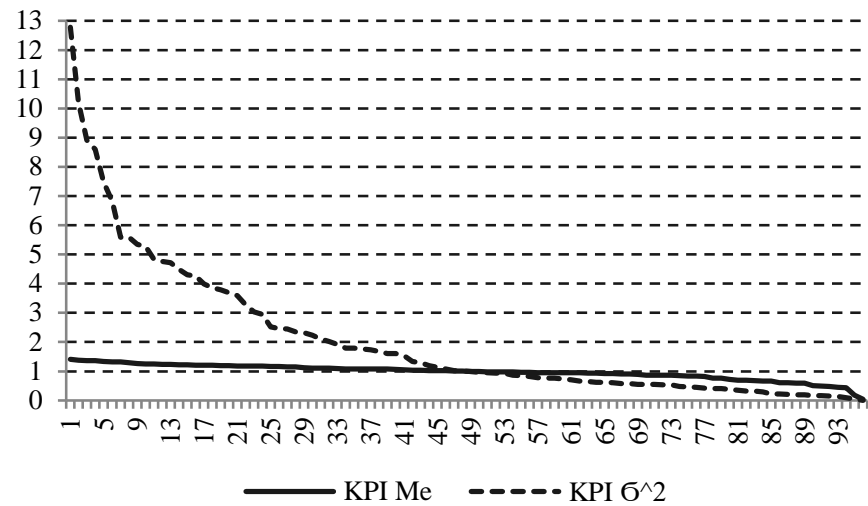

Fig. 1. KPI differentiation of the development of the economy of the regions of Russia, 2012-2017, Source: calculated and compiled according to the Federal State Statistics Service of the Russian Federation. "Regions of Russia Socio-economic indicators - 2018" Bank of ready-made documents. http://www.gks.ru/bgd/regl/b18_14p/Main.htm. Accessed on 09/18/2019.

KPI differentiation is primarily associated with high variance in the growth rate of KPI values for the development of the economy of subsidized regions, highly dependent on federal subsidies and subventions. It is subsidies and subventions, and not subsidies, when there is no responsibility for economic growth, that prevail in the economy of subsidized regions, and, accordingly, the main function of managing regional authorities is the distribution of these resources.

Due to federal subsidies and subventions, the alignment of $\mathrm{KPI}_{\mathrm{Me}}$ is observed (trend: $\mathrm{y}=-0.0088 \mathrm{x}+1.3998, \mathrm{R}^{2}=$ 0.8865 ), but the difference in $\mathrm{KPI}_{6}{ }^{2}$ is increasing (trend: $\mathrm{y}=$ $\left.9.2355 \mathrm{e}-0.045 \mathrm{x}, \mathrm{R}^{2}=0.881\right)$. In the future, this will cause an active decline in $\mathrm{KPI}_{\mathrm{Me}}$ development of the economy of the leading regions.

An analysis of changes in KPI dynamics (Figure 2) revealed a sharp increase in the value of fixed assets $(\mathrm{Me}=8.8 \%$, $\left.6^{2}=1222.9\right)$ and investments in fixed assets $(\mathrm{Me}=4.1 \%$, $6^{2}=215.8$ ) against the background of a sluggish stable decline in the number of labor at the age of 15-72 years $(\mathrm{Me}=-0.5 \%$, $\left.6^{2}=1.3\right)$ and real cash incomes of the population $(\mathrm{Me}=-1.4 \%$, $\left.6^{2}=5.8\right)$

A sharp increase in the value of fixed assets and investments in fixed assets is associated with a significant devaluation of the national currency $(01.01 .2012-\$ 1=32.19$ rubles; 01/01/2019 - $1 \$=69.47$ rubles; the maximum value $01 / 22 / 2016-\$ 1=83.59$ rubles) 


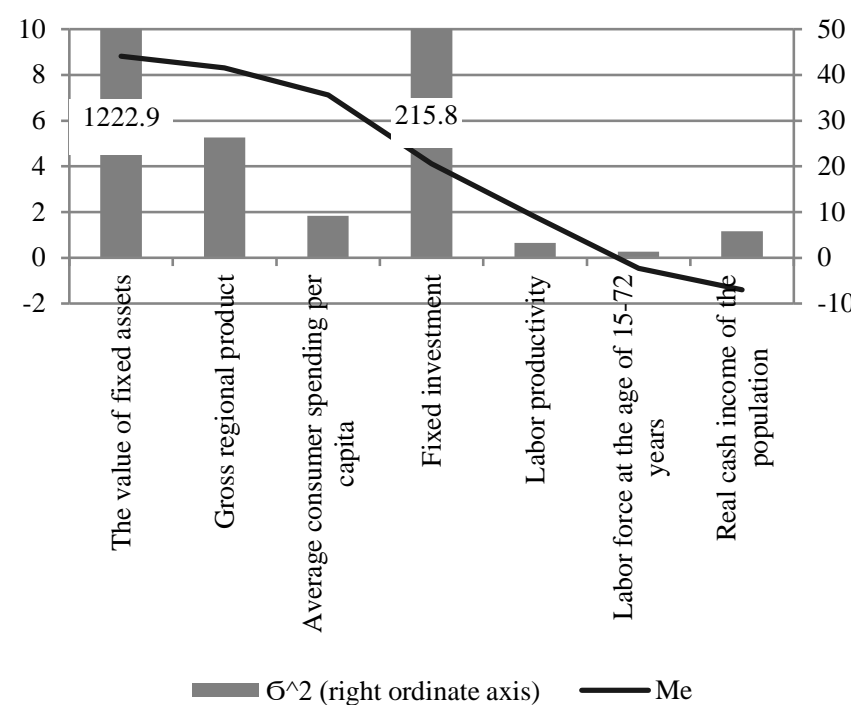

Fig. 2. Changes in the dynamics of KPI indicators, 2012-2017. Source: calculated and compiled according to the Federal State Statistics Service of the Russian Federation. "Regions of Russia. Socio-economic indicators 2018" Bank of ready-made documents. http://www.gks.ru/bgd/regl/b18_14p/Main.htm. Accessed on 09/18/2019.

\section{DISCUSSION OF RESULTS}

The KPI selection for the development of the region's economy was made in accordance with the requirements of the Federal Law "On Strategic Planning in the Russian Federation" and the Decree of the President of the Russian Federation "On Evaluating the Efficiency of the Activities of Senior Officials (Heads of the Highest Executive Bodies of State Power) of the Subjects of the Russian Federation and Activities of the Executive Bodies of the Subjects of the Russian Federation)" in the tier system of social reproduction. Thus, it becomes possible to give a systematic and targeted focus to the activities of state authorities for the development of regional business processes.

As a result of the KPI assessment of the development of the economy of the regions of Russia according to the main indicators of business activity (GRP; cost of fixed assets; labor force at the age of 15-72 years; investment in fixed assets; labor productivity; real incomes and average consumer spending per capita) identified by the list of indicators for assessing the performance of regional authorities revealed three levels of regional development according to $\mathrm{KPI}_{\mathrm{Me}}$ and $\mathrm{KPI}_{6}{ }^{2}$. In the aggregate $\mathrm{KPI}_{\mathrm{Me}}$ and $\mathrm{KPI}_{6}{ }^{2}$, the $\mathrm{KPI}_{\mathrm{Me}}$ leader is the Khanty-Mansiysk Autonomous Okrug - Ugra, specializing in oil and gas production (more than $80 \%$ ), electricity production (more than $6 \%$ ), processing industries (oil refineries and gas refineries).

For the raw material profile of the Russian economy, the following regions are developing actively enough: Vladimir, Volgograd, Voronezh, Irkutsk, Kirov, Kursk, Moscow, Omsk, Pskov, Rostov, Saratov, Sverdlovsk, Smolensk, Tomsk, Chelyabinsk and Yaroslavl regions; Republics - Tatarstan, Karachay-Cherkess, Karelia and Mordovia.

The raw material profile of the Russian economy allows, on the one hand, equalizing $\mathrm{KPI}_{\mathrm{Me}}$ of Russian regions due to federal subsidies and subventions, and on the other, to increase the $\mathrm{KPI}_{6}{ }^{2}$ gap, which will cause a cumulative decrease in $\mathrm{KPI}_{\mathrm{Me}}$ in the event of a significant drop in world hydrocarbon prices.

The increase in the value of fixed assets and investments in fixed assets, against the background of a sluggish stable decline in the number of workforce aged 15-72 years and real cash incomes of the population, is caused by a more than double devaluation of the national currency since 2012 .

\section{CONCLUSION}

Significant differences in the KPI of the development of the economy of the Russian regions are associated with high variance in the growth rates of the KPI of the development of subsidized regions, which are significantly dependent on federal subsidies and subventions. Stably high KPI values are to a greater extent shown by oil and gas regions as compared with the republics.

For a Russian economy with a commodity profile, a region that inherently does not have any political independence is a priority form of management and the best way to increase the KPI values of the development of Russian regions. Among the federal districts, the leader is the Ural and Central Federal Districts, in which there are no republics.

The optimal form of managing the Russian economy, aimed at increasing the KPI of regional economic development, is a unitary state, which the Republic of Tatarstan and Chechnya are actively trying to counteract, against the background of the absolute loyalty of the remaining regions of Russia.

\section{References}

[1] E. Domínguez, B. Perez, A.L. Rubio, M.A. Zapata, "A taxonomy for key performance indicators management", Computer Standards \& Interfaces, vol. 64, pp. 24-40, 2019. Retrieved from: https://doi.org/10.1016/j.csi.2018.12.001

[2] M. Badawy, A.A.A. El-Aziz., A.M. Idress, H. Hefny, S.S. Hossam, "A survey on exploring key performance indicators", Future Comput. and Inform. J., vol. 1, iss. 1-2, pp. 47-52, 2016. Retrieved from: https://doi.org/10.1016/j.fcij.2016.04.001

[3] G.S. Banu, "Measuring innovation using key performance indicators", Proc. Manufactur., vol. 22, pp. 906-911, 2018. Retrieved from: https://doi.org/10.1016/j.promfg.2018.03.128

[4] B. Javorcik, N. Sawada, "The ISO 9000 certification: Little pain, big gain?", Europ. Econ. Rev., vol. 105, pp. 103-114, 2018. Retrieved from: https://doi.org/10.1016/j.euroecorev.2018.03.005

[5] S. Cai, M. Jun, "A qualitative study of the internalization of ISO 9000 standards: The linkages among firms' motivations, internalization processes, and performance", Int. J. of Product. Econ., vol. 196, pp. 248-260, 2018. Retrieved from: https://doi.org/10.1016/j.ijpe.2017.12.001

[6] M. Terziovski, J.-L. Guerrero, "ISO 9000 quality system certification and its impact on product and process innovation performance", Int. J. of Product. Econ., vol. 158, pp. 197-207, 2014. Retrieved from: https://doi.org/10.1016/j.ijpe.2014.08.011

[7] A. Komm, B. Evenstein, "Best of the best: what the future holds for performance management systems", Vest. McKinsey, Manag., Theory and Pract., no. 34, 2019. Retrieved from: http://vestnikmckinsey.ru/ organizational-models-and-management-systems

[8] W.A. Cohen, "Peter Drucker Wants You to Be a Heroic Leader - Now", Organizat. Dynam., vol. 42, iss. 1, pp. 70-80, 2013. Retrieved from: https://doi.org/10.1016/j.orgdyn.2012.12.009

[9] S. Rosenberg, "Management challenges for the 21st century: Peter F. Drucker", Busin. Horizons, vol. 42, iss. 5, pp. 86-87, 1999. Retrieved from: https://doi.org/10.1016/S0007-6813(99)80080-9 
[10] D. Parmenter, Key Performance Indicators: Developing, Implementing and Using Winning KPI's. New Jersey, USA: John Wiley \& Sons, inc., 2007, $233 \mathrm{p}$

[11] R. Joppen, S. Enzberg, J. Gundlach, A. Kühn, R. Dumitrescu, "Key performance indicators in the production of the future", Proc. CIRP, vol. 81, pp. 759-764, 2019. Retrieved from: https://doi.org/10.1016/j.procir.2019.03.190

[12] E. Domínguez, B. Pérez, Á.L. Rubio, M.A. Zapata, "A taxonomy for key performance indicators management", Computer Standards \& Interfaces, vol. 64, pp. 24-40, 2019. Retrieved from: https://doi.org/10.1016/j.csi.2018.12.001

[13] V. Smirnov, V. Semenov, E. Kadyshev, A. Zakharova, I. Guschin, T. Kravchenko, M. Yaklashkin, O. Filippova, "Effective Public Administration of the Russian Economy", vol. 289, pp. 64-68, 2019 [Proc. of the Int. Conf. on Communicative Strategies of Information Society (CSIS 2018). Advances in Social Science, Education and Humanities Research]. Retrieved from: https://doi.org/10.2991/csis18.2019 .13

[14] V.V. Smirnov, D.G. Osipov, A.A. Babaeva, E.V. Grigorieva, E.F. Perfilova, "Parity of innovation and digital economy in the Russian management system", Modern Management Trends and the Digital Economy: from Regional Development to Global Economic Growth (MTDE 2019). Advan. in Econ., Busin. and Manag. Res., vol. 219 pp. 22-27. Retrieved from: https://doi.org/10.2991/mtde-19.2019.5

15] Federal law as of 28 June 2014, no. 172-FZ "On strategic planning in the Russian Federation", Collection of legislation of the Russian Federation of 30 June 2014, no. 26 (part I) of Art. 3378.

[16] Decree of the President of the Russian Federation as of 25 April 2019, no. 193 "On assessing the effectiveness of the activities of senior officials (heads of the highest executive bodies of state power) of the constituent entities of the Russian Federation and the activities of executive bodies of constituent entities of the Russian Federation", Collection of legislation of the Russian Federation of 29 April 2019 , no. 17 , Art. 2078

[17] Federal State Statistics Service of the Russian Federation, "Regions of Russia. Socio-economic indicators - 2018", Bank of ready-made documents. Retrieved from: http://www.gks.ru/bgd/regl/b18_14p/ Main.htm. Accessed on: 09/18/2019. 